\title{
Maqashid Sharia's Criticism of the Pareto Optimum Theory
}

\author{
Iwan Setiawan ${ }^{1 *}$ \\ Sharia Accounting Study Program, UIN Sunan Gunung Djati Bandung, Indonesia ${ }^{1}$.
}

Submitted: 12 October 2019, Accepted: 4 June 2020, Published: 8 June 2020

\begin{abstract}
This research analyzes the concept of maqashid sharia and the optimum Pareto theory. It was conducted in the form of library research, where data was obtained from literatures relating to the development of Islamic economics, the optimum Pareto theory, and maqashid sharia. Qualitative techniques were used to analyze unquantifiable data. The results show that the optimum Pareto theory has weaknesses and does not guarantee justice for the whole community. For instance, in achieving maximum efficiency, others must be sacrificed. This is contrary to the concept of Islamic economics which emphasizes justice for all parties to a transaction. Maqashid sharia has values that guide religion (din), soul (nafs), reasoning ('aql), property (mall), and offspring (nasab) as a reference to explain the weakness of the Pareto optimum theory. It applies especially in the distribution of wealth and welfare of the people. Pareto efficiency cannot be used as a basis for achieving economic goals since it is not impartial.
\end{abstract}

Keywords: Islamic economics, conventional economics, maqashid sharia, Pareto optimum 


\section{INTRODUCTION}

Compared to other ideologies, Islam has different systems and concepts (Kholish, 2015). Economic and business activities in Islam have a sense of justice. The basic values and general principles contained in the Al-Quran and Al-Sunnah are used as references in economic and business activities. These values include honesty, fairness, halal and social responsibility. Capitalistic liberal economics ignores moral and ethical dimensions (value-free).

According to Huda (2016), Islam and capitalist influences each other. In sociological studies, Islam was presented in a capitalist society, where the two had an attachment. Capitalism, especially Commercial, existed before Islam. Capitalism has significant influence on Islamic economics. In its development, Islamic teachings also influence and correct monetary status or prevailing capitalism. Therefore, Islam and capitalism interact and influence one another.

Islam formulates economics oriented to humans and society that does not recognize excessive individualism. It does not justify collectivity that violates individual rights based on the Qur'an ' and al-Sunnah (Fadlan, 2010). The purpose of Islamic economics is to create prosperity for all humanity, physical satisfaction, and mental peace. The fulfillment of spiritual and material needs can be realized through the development of humanity and resources. Therefore, the needs can be entirely fulfilled to attain a fair and equitable distribution of wealth.

Islamic economics has developed rapidly in various countries including Indonesia. Its development involves Islamic financial institutions and the discussion of the theories and methodologies used in their operations. The Islamic approach is oftenadopted because many phenomena in the economy cannot be explained by conventional systems. Therefore, Islamic economists continue to make formulations to examine theories and review conventional approaches. Apart from the use of usury, which is prohibited in Islamic economic activities, criticism such as optimum Pareto theory also destroys the conventional system.

The optimum Pareto theory is a general equilibrium condition to be achieved in every monetary activity in a conventional market. It describes an efficient balance. In Pareto conditions, society cannot increase their optimal level of satisfaction without harming others. If these conditions are met, welfare has been achieved for the community. This condition is the goal of conventional economic systems.

Maqashid Sharia's criticism of the optimum Pareto theory is based on the general balance analysis. This is because the optimum Pareto theory has weaknesses and contravenes the Islamic economic system. Denying the Maqashid Sharia criticism of the optimum Pareto theory is imperative because the concept of Islam in building a prosperous society must not harm others. 
The research on the criticism of Islamic economics on the optimum Pareto theory with the analysis of sharia principles and maqashid sharia has not been studied appropriately. The discussion of Islamic principles and maqashid sharia is a responsibility of all Muslims consistently and sincerely.

\section{METHOD}

This was library research which used qualitative techniques. Library studies are carried out using literature, both in the form of books, notes, and results of previous studies. Data collection was conducted several stages in collecting data, starting with the selection of material in the form of books, and journals. The data was then selected by prioritizing published works. The reference works are chosen based on the author's competence, and the level of novelty (Arikunto, 2008).

The data sources in this study were obtained indirectly (Sugiyono, 2010). From the literature relating to the development of Islamic economics, the optimum Pareto theory, and maqashid sharia. Furthermore, data analysis is performed using qualitative techniques that cannot be measured or valued directly by numbers. In general, descriptive research explains the existing social phenomena by developing concepts and gathering facts without hypothesis testing (Suryabrata, 2010). In this study, the descriptive analysis method is used to describe Maqashid sharia's criticism of the optimum Pareto theory.

\section{RESULTS AND DISCUSSION}

\section{Economic Development in Islam}

The concept of freedom in Islam (In'amuzzahidin, 2015) originates from the Ikhtiyar and taqdir which discusses whether humans are free to carry out their actions based on theology or religion. Furthermore, the concept of individual freedom in Islam is limited by the rights of others. Therefore, freedom in Islam is more limited and directed. The economic system of capitalism and socialism has made Muslims feel oppressed and constrained (Jayanti \& Ghozali, 2018). However, they have always endured these challenges to maintain their economic contributions.

In the capitalist system, productive assets and/or factors are mostly owned by the individual/private sector (Itang \& Daenuri, 2017). A socialist system is a form of resistance from the capitalist blamed for not achieving equity in welfare and wealth distribution. In this system, the government plays a significant role in regulating the economy in a country. 
The Islamic economic system is a branch of science that seeks to view, research, and solve problems in an Islamic way based on the Qur'an, As-Sunnah, ijma 'and qiyas. Islamic values have existed from the time of the Prophet Muhammad. The Islamic economic building framework consists of five universal values, including Tawhid, 'Adl, Nubuwwah, Khilafah, and $M a^{\prime} a d$. Additionally, the three derivative values include Multi-type Ownership, Freedom to Act, and Social Justice. All these aspects are covered by Akhlak al-Karimah.

The capitalist system is influenced by the spirit to gain maximum benefit with limited resources (Muhalling, 2017). This system is characterized by the freedom to own personal assets. The socialist system is influenced by the philosophy of obtaining welfare together. This system emphasizes property ownership by the government and has some positive aspects. For instance, the basic needs, production, and economic traffic is planned and fulfilled by the state. The Islamic economic system has special characteristics. For example, Islam recognizes human freedom to create in an economy based on monotheism, wealth needs to be distributed with the rights of others, specifically the Fakir and the Poor. Therefore, there is an obligation to share through Zakat, Infaq, and Sadaqah in Islam.

The Islamic system provides solutions in realizing socio-economic goals, making Islam a way of life, building collective awareness of the people with a solid economic interwoven, accommodating the values of faith in every activity, composing strategic work patterns, and empowering the Islamic financial institutions to manage investment funds from all Muslims for mutual trust and honesty.

The failure of conventional systems, both socialist and capitalist, necessitates the search for the best system solutions by experts. The solution has been offered by previous economists, such as Umer Chapra (2001) through his book The Future of Economics: An Islamic Perspectives are Islamic Economics. In general, Islamic Economics refers to a system whose sources are governed by the Qur'an and the Hadith. Its sharia guidelines aim at human maslahah and falah.

Rahmawaty (2013) attributed the problems of injustice and inequality in the distribution of current income and wealth to the market economy system, which is unable to create fairness and justice in the global economy. Islam offers a distribution system that prioritizes the value of freedom of action based on religious teachings. It also emphasizes justice in ownership, which is based on two joints, including freedom and justice with economic and non-economic mechanisms.

According to Septiana (2016), human behavior in Islamic economics, including consumption, must be based on the guidance of the Qur'an and Hadith, as well as needs to be based on rationality. For example, in conventional banking operations, there are activities prohibited by Islamic sharia, including receiving and paying interest (usury), financing production, and trading goods that are prohibited from sharia (Budiman, 2014). 
The capitalist and socialist systems have been unable to promote welfare and justice for both individuals and society (Tho'in, 2015). The Islamic system is a middle way that combines the economic system of capitalism and socialism. This unification effort was carried out to take the positive and dynamic sides of the two systems.

The Islamic Economy has a strategy for development, such as the reorganization of a whole economic system with four mutually reinforcing elements, including filter mechanism, motivation, socio-economic restructuring, and the role of the state (Sunjoto, 2018). Furthermore, there are suggested policies to solve problems in Muslim countries, including reviving humanitarian factors and financial restructuring.

Islam perceives development as the growth of human maturity, in which material advances should support spiritual maturity (Almizan, 2016). Islamic economics advocate for a balance between individual and societal interests. Material benefits for a Muslim is an intermediary goal to achieve human ideals in the form of obedience to Allah.

Fitria (2016) stated that Islamic economic development is based on an understanding of sharia, sourced from the Quran and al-Hadith, emphasizing that the success of development needs to be accompanied by knowledge of classical and modernism concepts, as well as the experiences of countries that have succeeded in development. Islamic economy is a complete human development that involves both physical needs, spiritual, and mental growth (Djumadi, 2016). According to Islam, economic development should focus on (a) the benefit of humanity from extinction, (b) human resources, where good human resources reflect Halal income sources (SPH), (c) protect and preserve natural ecosystems from damage, and (d) maximum land utilization and paying taxes to the state. Economic growth in the Islamic economy is perceived as the most important part of policy in the country and the financial system in the world(Muttaqin, 2018).

Economic development in a country should focus on improving the welfare and happiness of humans in the world and the hereafter (Purwana, 2013). Islamic economics is an analytical model for Muslims and will reduce absolute dependence on conventional financial analysis tools (Mudawam, 2000).

\section{The Pareto Optimum Theory}

According to Purbaya (2016), the current economy is at a crossroads. The potential to grow is increasingly open because the whole nation is well aware of the need for equity as a precondition for social justice realization. The economic system used in the world is still controlled by conventional systems of capitalism and socialism (Muhalling, 2017). These systems show increased prosperity in the community. However, there are still many shortcomings that cannot be resolved by both systems. In principle, the economic system aims 
to create social-economic justice and community prosperity. Therefore, it is important to study more deeply since both systems have failed to realize their objectives. It is necessary to examine the differences between both systems and compare them with the Islamic principles.

Kholis (2008) stated that conventional economics has both weaknesses and advantages. The weakness lies in the secular paradigm that separates positive and normative economics, the absence of a strong relationship between micro and macroeconomics, as well as the neglect of moral and ethical values in their descriptive and predictive functions. The advantage lies in the achievement of conventional theories with mathematical and calculus models. The globalization era and development have led to many opportunities and challenges, especially in efforts to develop Islamic economics. Therefore, the development of Islamic economics should be based on the successes and failures of conventional systems.

The capitalist system prioritizes the role of capital, such as producer goods. This system emerged in a mercantilism and colonialism period pioneered by three major world economists, Adam Smith, Martin Luther, and Benjamin Franklin (Jayanti \& Ghozali, 2018). In the capitalist system, individuals play more roles than the government. The government is only entitled to give freedom to investors to develop businesses. The capitalist system prioritizes individual ownership rights since they have absolute rights. However, it has also killed the economies of developing or poor countries (Huda, 2016)

A socialist system is a form of rejection from capitalism. This is because the capitalist system is considered to be the cause of unequal welfare (Tho'in, 2015). The socialist system prioritizes togetherness (collectivism), where the government plays a critical role. It also has weaknesses due to the overly dominant role of the government, such as difficulties in carrying out transactions, limited innovation freedom, and ignoring moral education because the market mechanism is established by the government (Itang \& Daenuri, 2017).

Microeconomic studies on the general equilibrium framework analysis largely explain the theory through optimum Pareto analysis. General equilibrium analysis determines prices and quantities in all markets simultaneously. Specifically, it is an analysis that considers the feedback effect. In case there is a substitute or complementary item from another market, the difference is offset. Therefore, in conducting a general balance analysis, the equilibrium attained in terms of price and quantity from the market and the impact on the balance in other markets are considered (Pindyck \& Rubinfeld, 2013).

The most widely used criteria in assessing welfare economics are the Pareto techniques proposed by Vilfredo Pareto (Arsyad, 1999). A change in circumstances is said to be good or feasible; in case it has benefits and no party loses. Microeconomic studies show that Pareto's theory has three types of welfare levels. The optimal Pareto level occurs when an increase in the welfare of a person or group reduces the welfare of another person or group. 
Second, Non-optimal Pareto conditions occur when a person's welfare does not reduce the welfare of others. Third, the superior Pareto condition occurs when an increase in one's welfare cannot reduce the highest welfare of others. According to the Pareto theory, in case the community welfare condition has reached the optimal level, there is no need for any government policy.

Optimum Pareto cannot be used to solve basic social problems of distribution and redistribution. Welfare economics with problems in allocation are rectified by considering changing values. These changing value judgments apply to conventional welfare functions, though not a solid basis of economics.

According to optimum Pareto, a prosperous community cannot be efficient without sacrificing the prosperity of other communities (Case \& Fair, 2007). Therefore, the economy is efficient in case there is an optimization of the utility or welfare of one party by reducing the utility or welfare of the other party. This is to be achieved in optimizing Pareto.

Several things need to be considered in the Pareto criteria, including improvement and efficiency, which affect the decision making of economic policy. Pareto improvement occurs in case the change decision makes one party better off without making the other one worse off. Pareto efficiency is a condition in which there is no longer a change that can result in a party becoming better off without causing another party to be worse off.

The discussion of efficiency in an exchange economy is critical and requires a clear understanding. Economic efficiency is a competitive and efficient market that maximizes the aggregate surplus of consumers and producers. Therefore, efficiency in an exchange economy is a behavioral analysis of consumers trading and benefiting through the exchange (Pindyck \& Rubinfeld, 2013). According to Vilfredo Pareto, a market cannot be efficient without causing other markets to be inefficient (Pamungkas, Wahyunadi, \& Firmansyah, 2016). Therefore, it is not possible to achieve optimum efficiency together without weakening the market or other consumers. This means that optimum efficiency can only be enjoyed by one party.

Pareto efficiency can be perfectly explained based on the analysis of profitability and what makes some people more profitable than others (Case \& Fair, 2007). A person can be more profitable or harmed after the exchange, however, almost every change that someone describes allows for a more profitable or harmed party. In case there is a profitable or harmed party due to the effect of the change, and the profit is greater than the loss, the change is potentially efficient.

\section{Edgeworth Box}

The Edgeworth Box is used to analyze efficiency in an exchange economy. It explains trade occurs, the activity efficiently allocates goods among consumers, and profitability (Pindyck \& Rubinfeld, 2013) 
The explanation on the Edgeworth box is based on two individuals combining both commodities owned. Individuals $\mathrm{A}$ and $\mathrm{B}$ have each preference and endowments. Consumption for individual $\mathrm{A}$ is $\mathrm{C}_{\mathrm{A}}=\left(\mathrm{C}_{\mathrm{A}}^{\mathrm{X}}, \mathrm{C}_{\mathrm{A}}{ }^{\mathrm{Y}}\right)$, where $\mathrm{C}_{\mathrm{A}}{ }^{\mathrm{X}}$ and $\mathrm{C}_{\mathrm{A}}{ }^{\mathrm{Y}}$ represent the consumption of commodity $X$ and $Y$, respectively. Similarly, consumption for individual $B$ is $C_{B}=\left(C_{B}{ }^{X}, C_{B}{ }^{Y}\right)$, where $C_{B}{ }^{x}$ and $C_{B}{ }^{Y}$ the consumption of commodities $X$ and $Y$, respectively. The $C_{A}$ and $C_{B}$ are at a fair level of consumption through allocation. Allocation for the consumption of commodity $\mathrm{X}$ and $Y$ is limited by the total supply of commodities $X$ and $Y$, specifically $C_{A}{ }^{X}+C_{B}{ }^{x}=u_{A} \cdots{ }_{A}+w_{B} \cdots{ }_{B}$ and $\mathrm{C}_{\mathrm{A}}{ }^{\mathrm{Y}}+\mathrm{C}_{\mathrm{B}}{ }^{\mathrm{Y}}=\mathrm{w}_{\mathrm{A}}{ }_{\mathrm{A}}^{\mathrm{Y}}+\mathrm{w}_{\mathrm{B}}{ }_{\mathrm{B}}^{\mathrm{Y}}$, until a new efficient utility balance is reached. Consider the following Edgeworth Box picture: (Karim, 2010).

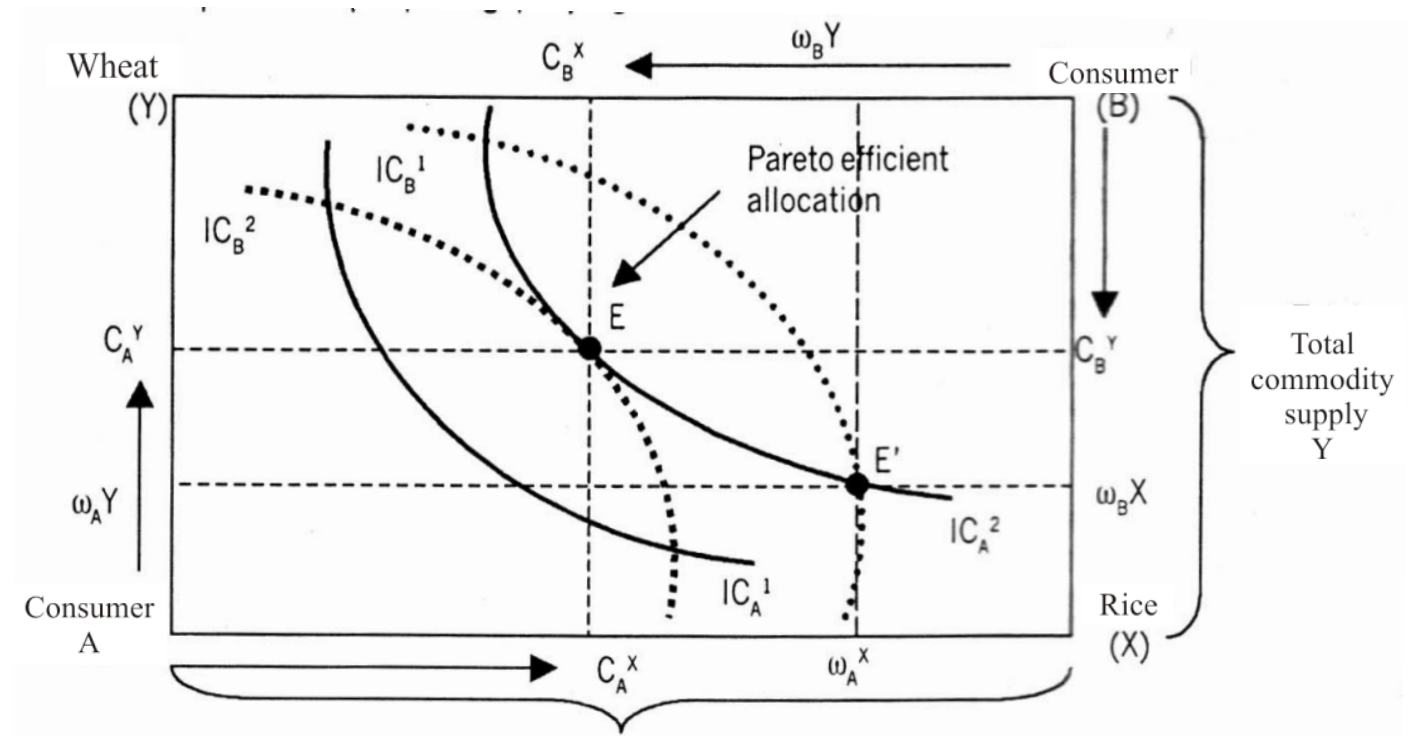

Total commodity supply X

Figure 1. Edgeworth Box

The Edgeworth Box is a combination of utility functions and indifference curves of two individuals interacting in economic exchange. In this box, the optimum Pareto efficiency can be achieved in case individual indifference curves 1 and 2 will intersect at one point. The intersection cannot occur at one point but can occur at other points which are also efficient Pareto for both individuals. The efficient allocation of the two is dependent on the utility function of each individual and their ability to make an offer for a more satisfying efficient allocation. The combination of points that show the efficient allocation of the two individuals forms a Contract curve because at these points the utility of one individual can no longer be added without reducing that of the other individual (Pareto optimum).

Anggrianto (2019) themed the concept of justice in the optimum Pareto theory according to Umer Chapra. In general, Umer Chapra's thoughts include the concept of falah, hayyah thayyibah, and the economic challenges of Muslims, monetary policy, sharia financial 
institutions more aligned to the central bank, and its policies, as well as the concept of a prosperous state according to Islam. Chapra emphasizes the moral importance of a fair and healthy economy.

\section{Maqashid sharia}

Capitalist (conventional) economics aim to maximize profits as much as possible and avoid losses. The advantages of capitalists include freedom, increased production, and profits. There are some fundamental weaknesses including the occurrence of inequality in wealth, maximum profit, capital crisis, materialism, and the exclusion of welfare in its activities (Budiman, 2014). Therefore, capitalism is not in line with the Islamic economic system, and the objectives of the activities taught in Islam are no longer realized, including achieving world safety and the hereafter.

As a solution to the weaknesses of the capitalist system, Islam adopts maqashid sharia principles. Maqashid sharia is an Islamic economic system that aims to realize goodness, avoiding badness, attracting benefits, and rejecting mudharat (Febriadi, 2017). Therefore, the goal that cannot be achieved by the conventional system can be realized using maqashid sharia.

This section reviews Islamic economics in general with maqashid sharia values, including guarding the religion (din) (Febriadi, 2017). In realizing this goal, the Qur'an, the hadith, and other Islamic laws are used as guidelines in running all systems. By referring to the Qur'an and hadith, all activities are based on Islamic values and rules can be maintained. Second, guarding the soul (nafs) is realized from the contracts applied in every transaction. Psychologically and sociologically, the use of agreements between parties leads humans to respect each other and maintain the mandate given to each party, which is called the value of the soul. Furthermore, in transactions, individuals are guided to behave and communicate politely. Third, guarding the mind ('aql) requires that all parties disclose in detail every economic activity and are prohibited from hiding, even for the slightest defect. The parties to a transaction are supposed to carry out activities without being wronged by each party. They should explain to each other the conditions of the object being transacted. Fourth, guarding the property (mall) is manifested clearly in every economic activity that seeks to maintain and allocate resources owned properly and halal. The individuals are allowed to make reasonable profits. It is also evident in the application of the zakat system, which aims to clean up assets obtained from economic activities. Fifth, guarding offspring (nasab) is realized with the preservation of the four elements explained before. Therefore, the assets obtained are guaranteed halal and may have a positive impact on families and offspring supported from the assets obtained.

The purpose or concept of the Maqașid Sharia is to preserve the interests and benefits of human beings (Syufa'at, 2013). Therefore, it can be used as a blueprint in dealing with various contemporary economic problems, both theoretical and practical. 
Obtaining benefit is the basis for humans to realize goodness (Ghulam, 2016). This is because the principle of benefit is the base of the concept of sharia objectives (maqashid sharia). The benefit base comes from al-Qur'an and al-Hadith. From them, humans do ijtihad to determine benefits idealized in life and life.

Maqashid sharia is a general goal to be achieved by sharia and manifested in life (Febriadi, 2017). They are important concepts in the study of Islamic law. The economic system is stated to be successful in case it makes the community prosperous. Therefore, the system should be able to strive to achieve its main goal of social welfare. Maqashid sharia and maslahat are used as analysis tools in answering issues relating to sharia economics and businesses growing today (Nurnazli, 2014). The obligation of business experts is to always work hard to conduct studies related to sharia economic and business issues.

Research on Islamic economics based on maqashid sharia is very important. It shows that sharia has a concern in guiding what is allowed or prohibited in transactions. Additionally, it is built based on the maqashid sharia frame. The theory occupies a very central and important position in formulating the methodology of developing Islamic economics.

\section{Islamic Economic System: Principles}

Human problems are increasingly complex and there is a shift in values that ultimately affect sharia, including the economic field. This drives Islamists to reconstruct for Islamic law "Shalih likulli zaman wa makan" to be felt (Fuady \& Daud, 2018). Therefore, it is necessary to restudy the reconstruction of law in order not to harm the sharia provisions.

One difference between the Islamic and the conventional system is the paradigm of life with all its activities (Mursal, 2015). The Islamic economy position is a basis of belief in carrying out activities in social interactions and financial transactions. Monotheism is expected to form integrity that helps form a good economic concept. The principle of justice is an obligation in the enforcement of Islamic law. By implementing Islamic principles in all aspects, equitable welfare can be realized. Therefore, economics involves pursuing both material gains and spirituality.

The Islamic system is very different from the existing system. In some cases, it is considered contrary to the conventional approach. It is advantageous compared to other systems (Kholish, 2015). The Islamic economy continues to formulate theories and a review of conventional formulas established at this time because many phenomena cannot be explained.

Islamic economics is based on the key foundation of freedom and justice (Rahmawaty, 2013). Freedom means being free in managing the potentials and natural resources given by Allah as a caliph (In'amuzzahidin, 2015). The meaning of justice is emphasized on the benefits that occur in economic activities and avoiding usury, Masyir, gharar, and everything unlawful (Mursal, 2015). 
The Islamic economic system is based on values contained in the Al-Quran and AlHadith (P3EI, 2015). It is a branch of science that seeks to view, analyze, and ultimately solve problems in an Islamic way.

The principles of fundamental rules in building an Islamic framework include resource utilization, compensation, efficiency, professionalism, sufficiency, equal opportunity, freedom, cooperation, competition, equilibrium, solidarity, and symmetric information (P3EI, 2015).

In carrying out economic activities, Muslims must pay attention to sharia principles contained in the Qur'an and Hadith. Islam does not prevent a person from becoming wealthy, but gaining wealth must be following Islamic law. In every wealth of Muslims, there is a portion of assets that must be distributed to others. This is carried out to guarantee private ownership while at the same time ensuring an equitable distribution of income.

\section{The Weakness of the Pareto Optimum Theory}

The capitalist system has the principle of gaining the maximum profit by making the smallest sacrifices. The conventional economic principle is used by traders and companies that only focus on profit. Even consumers want maximum profits exceeding the capital spent and its capabilities. This principle eventually makes someone greedy in seeking profit and fulfilling needs. Based on this, the capitalist system is built with optimum Pareto balance analysis.

The study of the Pareto optimum concept shows injustices that are contrary to the Islamic economic system. This means that the allocation of efficiency in the community is unfair due to the wide gap occurring in the community. An injustice is perceived as a positive thing in case it was in line with Pareto efficiency. The optimum Pareto concept does not guarantee justice in society, a condition that hinders prosperity.

This happens because the error lies in the formulation of the optimum Pareto concept and the process occurring in the analysis in the Edgeworth box. In the contract curve analysis in the Edgeworth box, resource allocation will always be efficient. A point on the contract curve can provide the maximum allocation to one of the desired parties. This leads to a very small allocation of resources to the other party. According to the Pareto optimum concept, this is the best point because the allocation of resources reaches its best level. Furthermore, the party that gets the smallest allocation is considered to have achieved the best allocation of resources because it cannot increase utility anymore. This is because an increase makes parties with very large utilities worse-off and disrupt economic efficiency. The condition shows injustice towards the poor community and is contrary to the value of guarding religion (din) in the maqashid sharia, the principle of being fair. Therefore, in case the economy is based on the Pareto optimum system only, injustice will prevail.

Optimum Pareto still has other weaknesses such as endowment from each party. For instance, it is often shown in the same endowment and has a balance between the two parties involved in economic activities in exchanges. Both parties have equal individual efficiency in the middle of the endowment box. An exchange economy often occurs between people with 
large and small capital. The very striking difference in endowments provide greater benefits to individuals with large capital and not to those with smaller endowments. This is contrary to the value of guarding the soul (nafs), where the use of economic activity contracts between parties leads to mutual respect and maintain the mandate given.

The optimum Pareto concept has assumptions that are very vulnerable and difficult to occur in real life. The first assumption is that both parties in an exchange know each other's preferences. This is very difficult because the information is not symmetrical in the market. The second assumption is the cost of exchanging goods that do not exist. This is contrary to the value of guarding reason ('aql), where economic actors are invited to reason with each other in transactions.

Analysis of the efficient allocation balance of companies or individuals achieves efficiency in case it has maximized utility. In the Islamic economic system, individuals are demanded not to over-apply and exploit the favors of Allah. Therefore, in applying the Pareto efficiency analysis, which is built from the utility function and production possibility curve function, it causes damages. This is contrary to the value of guarding assets (malls), where each activity seeks to maintain and allocate resources owned properly and lawfully and allowing individuals to take reasonable profits. It also contradicts the value of guarding offspring (nasab), assets obtained from economic activities guaranteed to be halal have a good impact on families and offspring supported.

The optimum Pareto concept contravenes the Islamic economic view in achieving prosperity. Islamic system is comprehensive and sees many shortcomings in the conventional economic system, especially in the optimum Pareto concept.

\section{CONCLUSION}

This study shows that optimum Pareto theory has weaknesses. For instance, it does not guarantee justice for the whole community; were to achieve maximum efficiency, others should be sacrificed. This is contrary to the concept of Islamic economics which emphasizes justice for those transacting. Maqashid sharia has the values of guarding religion (din), soul (nafs), reason ('aql), property (mall), and offspring (nasab). These values are used to explain the weakness of the Pareto optimum theory, especially on the distribution of wealth and prosperity of the people. Pareto efficiency cannot be used as a basis in achieving economic goals since it is partial. 


\section{BIBLIOGRAPHY}

Almizan. (2016). Pembangunan Ekonomi dalam Perspektif Ekonomi Islam, Maqdis: Jurnal Kajian Ekonomi Islam, 1(2), 203-222. DOI: http://dx.doi.org/10.15548/maqdis.v1i2.46

Anggrianto, L. (2019). Konsep Keadilan dalam Teori Pareto Optimum menurut Umer Chapra, Skripsi Institut Agama Islam Negeri Bengkulu.

Arikunto, S. (2008). Prosedur Penelitian Suatu Pendekatan Praktek. Cet. 12, Jakarta: PT Rineka Cipta.

Arsyad, L. (1999). Ekonomi Mikro, Jakarta: Gemapress.

Budiman, A. (2014) Kapitalisme Ekonomi Syariah', An-Nisbah, 1(1), 48-71. DOI: 10.21274/ an.2014.1.1.47-71.

Case, K. E., \& Ray C. F. (2007). Prinsip-Prinsip Ekonomi Mikro, ed. by Bambang Sarwiji, 7th edn. Indonesia: Indeks.

Chapra, M. U. (2001). The Future of Economic An Islamic Perspective, terjemah, Ikhwan Abidin Basri: Masa Depan Ilmu Ekonomi, Sebuah Tujuan Islam, Bandung: Gema Insani.

Djumadi. (2016). Konsep Pembangunan Ekonomi Perspektif Islam, Tahkim, 12(1), 1-16. DOI: http://dx.doi.org/10.33477/thk.v12i1.25.

Fadlan. (2010). Konsep Pembangunan Ekonomi Berbasis Islam (Sebuah Upaya Pembangunan Ekonomi Indonesia yang Adil, Makmur, dan Sejahtera), Al-Ahkam, 5(2), 257-274. DOI: http://dx.doi.org/10.19105/al-ihkam.v5i2.293

Febriadi, S. R. (2017). Aplikasi Maqashid syariah dalam Bidang Perbankan Syariah, Amwaluna: Jurnal Ekonomi dan Keuangan Syariah, l(2), 231-245. DOI: https:/doi.org/ 10.29313/amwaluna.v1i2.2585.

Fitria, T. N. (2016). Kontribusi Ekonomi Islam dalam Pembangunan Ekonomi Nasional, Jurnal Ilmiah Ekonomi Islam, 2(3), 29-40. DOI: http://dx.doi.org/10.29040/jiei.v2i03.3.

Fuady, Z, \& Daud, M. (2018). Menyoal Rekonstruksi Maqashid dalam Pembaharuan Hukum Kewarisan Islam, Jurnal Ilmiah Islam Futura, 18(1), 1-33. DOI: http://dx.doi.org/ 10.22373/jiif.v18i1.2843.

Ghulam, Z. (2016). Implementasi Maqashid Syariah dalam Koperasi Syariah, Iqtishoduna, 5(1), 90-112.https://ejournal.iaisyarifuddin.ac.id/index.php/iqtishoduna/article/view/85.

Hasan, M. I. (2002). Pokok-pokok Materi Metode Penelitian dan Aplikasinya. Bogor: Ghalia Indonesia.

Huda, C. (2016). Ekonomi Islam dan Kapitalisme (Merunut Benih Kapitalisme Dalam Ekonomi Islam)', Economica, 7(1), 27-49. DOI: http://dx.doi.org/10.21580/economica.2016.7. 1.1031 .

In'amuzzahidin, M. (2015). Konsep Kebebasan dalam Islam, At-Taqaddum, 7(2), 259-276. DOI: http://dx.doi.org/10.21580/at.v7i2.1206. 
Itang \& Daenuri, A. (2017). Sistem Ekonomi Kapitalis, Sosialis dan Islam', Tazkiya, 18(1), 67-91.http://jurnal.uinbanten.ac.id/index.php/tazkiya/article/view/1143.

Jayanti, K. F., \& Ghozali, M. (2018). Penerapan Sistem Ekonomi Syariah di Negara Minoritas Muslim', Equilibrium, 6(1), 109-123. DOI: 10.21043/equilibrium.v6i1.3555.

Karim, A. A. (2010). Ekonomi Mikro Islam, 3rd edn. Jakara: PT Rajagrafindo Persada.

Kholis, N. (2008). Masa Depan Ekonomi Islam dalam Arus Trend Ekonomi Era Global, UNISIA: Jurnal Ilmu-Ilmu Sosial, 31(68), 1-23. DOI: https://doi.org/ 10.20885/unisia.vol31.iss68.art5.

Kholish, A. (2015). Wawasan Sistem Ekonomi Islam, Jurnal Studi Islam Miyah, 11(2), 259 280. DOI: http://dx.doi.org/10.33754/miyah.v11i2.18.g18.

Mudawam, S. (2000). Ekonomi Islam dalam Prospek Pembangunan Umat Islam, Jurnal Ekonomi dan Studi Pembangunan, 1(2), 109-123. https://journal.umy.ac.id/index. article/view/1453.

Muhalling, R. (2017). Kontestasi Sistem Ekonomi Islam dan Konvensional, Li Falah; Journal of Islamic Economics and Business Studies, 2(1), 92-112. DOI: http:/dx.doi.org/ 10.31332/lifalah.v2i1.605.

Mursal. (2015). Implementasi Prinsip-Prinsip Ekonomi Syariah: Alternatif Mewujudkan Kesejahteraan Berkeadilan, Perspektif Ekonomi Darussalam, 1(1), 75-84. DOI: https://doi.org/10.24815/jped.v1i1.6521.

Muttaqin, R. (2018). Pertumbuhan Ekonomi dalam Perspektif Islam (Economic Growth in Islamic Perspective), Maro, Jurnal Ekonomi Syariah dan Bisnis, 1(2), 117-122. DOI: http://dx.doi.org/10.31949/mr.v1i2.1134.

Nurnazli. (2014). Penerapan Kaidah Maqâshid Syariah dalam Produk Perbankan Syariah. Ijtimaiyya, 7(1), 43-63. DOI: https://doi.org/10.24042/ijpmi.v7i1.917.

Pamungkas, B. D., Wahyunadi, \& Firmansyah, M. (2016). Analisis Efisiensi Puskesmas di Kabupaten Sumbawa Tahun 2015', Jesp: Jurnal Ekonomi dan Studi Pembangunan, 8(2), 182-203. DOI: http://dx.doi.org/10.17977/um002v8i22016p183.

Pindyck, R. S., \& Daniel L. R. (2013). Mikro Ekonomi, ed. by Novietha I. Sallama, 8th edn. Jakarta: Erlangga.

Purbaya, A. G. (2016). Strategi Peningkatan Kesejahteraan Ekonomi Masyarakat: Kasus Pengusaha Krupuk dan Camilan Hasil Laut di Pantai Kenjeran Lama Surabaya, OECONOMICUS Journal of Economics, 1(1), 71-98. DOI: https://doi.org/ 10.15642/oje.2016.1.1.71\%20-\%2098.

Purwana, A. E. (2013). Pembangunan dalam Perspektif Ekonomi Islam, Justitia Islamica, 10(1), 1-18. DOI: 10.21154/justicia.v10i1.140.

Pusat Pengkajian dan Pengembangan Ekonomi Islam (P3EI) Universitas Islam Indonesia Yogyakarta atas kerja sama dengan Bank Indonesia. (2015). Ekonomi Islam, 7th edn. Jakara: PT Rajagrafindo Persada. 
Rahmawaty, A. (2013). Distribusi Ekonomi Dalam Islam Upaya Pemerataan Kesejahteraan Melalui Keadilan Distributif', Equilibrium, 1(1), 1-17. DOI: 10.21043/equilibrium. v1i1.198.

Septiana, A. (2016). Analisis Perilaku Konsumsi dalam Islam, Jurnal DINAR Ekonomi Syariah, 2(1), 1-9. DOI: https://doi.org/10.21107/dinar.v2i1.2688.

Sugiyono. (2010). Metode Penelitian KuantitatifKualitatifdan R\&D. Bandung: Alfabeta.

Sunjoto, A. R. (2018). Strategi Kebijakan Pembangunan Ekonomi dalam Perspektif Islam (Studi Kritis Terhadap Pemikiran Ekonomi Neo Klasik), Islamic Economic Journal, 4(1), 1-17. DOI: http://dx.doi.org/10.21111/iej.v4i1.2896.

Suryabrata, S. (2010). Metodologi Penelitian. Jakarta: Rajawali Pers.

Syufa'at. (2013). Implementasi Maqāṣid Al-Sharī'ah dalam Hukum Ekonomi Islam, AlAhkam: Jurnal Pemikiran Hukum Islam, 23(2), 143-166. DOI: http://dx.doi.org/10. 21580/ahkam.2013.23.2.20.

Tho'in, M. (2015). Konsep Ekonomi Islam Jalan Tengah (Kapitalis - Sosialis)', Ilmiah Ekonomi Islam, 1(3), 118-33. DOI: http://dx.doi.org/10.29040/jiei.v1i03.34 